\title{
Estimation of sea level rise and storm surge risks along the coast of Estonia, Baltic Sea - a tool for coastal management
}

\author{
Ülo Suursaar, Estonian Marine Institute, University of Tartu, ulo.suursaar@ut.ee \\ Jaak Jaagus, Institute of Ecology and Earth Sciences, University of Tartu, jaak.jaagus@ut.ee \\ Tiit Kullas, Estonian Marine Institute, University of Tartu, tiit.kullas@ut.ee \\ Hannes Tõnisson, Institute of Ecology at Tallinn University, hannest@gmail.com
}

\begin{abstract}
The aim of the paper is to present statistical analysis of the sea level data obtained from the Estonian coastal tide gauges over the period 1842-2009, to assess storm surge risks and to discuss climate change related mitigation and management issues in the coastal zone of Estonia. Long-term variations of both mean and extreme sea level values were studied in the Eastern section of the nearly tideless Baltic Sea. Influenced by postglacial land uplift, the series of relative sea level displayed slightly varying trends. The remarkably steep rise in annual maximum sea levels $(2-12 \mathrm{~mm} / \mathrm{yr})$ could be explained by the local response to the changing regional wind climate. Due to its windward location, the sea level variations in the semi-enclosed study area are sensitive to the changes in cyclonic activity. Maximum value analysis revealed that in case of the south-westerly exposed Pärnu Bay, two storm surge events (253 in 1967 and $275 \mathrm{~cm}$ in 2005) were inconsistent with the theoretical distributions, which indicate that, in some locations, the most extreme sea level events are hardly predictable by means of return statistics. The parameters of maximum expected storm surges were estimated on the basis of hydrodynamic modelling.
\end{abstract}

Keywords: sea level trends, storm surge, flood risk, climate change

\section{Introduction}

Climate change and present-time sea level rise manifests in different locations in different ways [Emery and Aubrey, 1991; IPCC, 2007]. The concept of a "global sea level trend" and attempts to identify a "climate signal" in sea level rise play a central role in the current climate change research [Smith et al., 2000]. However, in coastal zone management, which is usually a local issue, the developments in the relative sea level, i.e. the values locally observed in the tide gauge stations, are equally important. "Sea level" is understood as relative sea level throughout this paper, if not otherwise specified. In a fixed location, there are three main factors influencing its long-term variations: global sea level change, regional land uplift or subsidence and changes in the water balance of the particular sea [BACC, 2008].

Estonia lies in the northern hemisphere's zone of moderate latitudes $\left(58^{\circ}-60^{\circ} N\right)$ in the eastern section of the semi-enclosed Baltic Sea (Fig. 1). The coastal sea of Estonia is heavily indented and shallow. With amplitudes of $M_{2}$ and $K_{1}$ waves measuring less than 5 $\mathrm{cm}$, the study area is nearly tideless [Lazarenko, 1986; BACC, 2008]. However, the frequent

This is an Open Access article distributed under the terms of the Creative Commons Attribution-Noncommercial License 3.0, which permits unrestricted use, distribution, and reproduction in any noncommercial medium, provided the original work is properly cited. 
occurrence of cyclones passing from west to east, and their corresponding changes in wind direction and speed, may create considerable sea level fluctuations there. As an exposed and windward coast, the area is also sensitive to changes in wind climate and storminess. While more than $95 \%$ of the sea level data fall within the range of -50 and $+60 \mathrm{~cm}$ in relation to the long-term mean, there are a few exceptional (up to $275 \mathrm{~cm}$ ) storm surges on record. Due to site-specific features, the West Estonian bays are subject to storm surge hazard. It is suggested that the flooding generated both by local storm surges and climatologically induced global sea level rise will increasingly affect the nearly tideless Estonian coastal zone [Kont et al., 2003; Suursaar et al., 2006]. The principal purpose of the article is to present statistical analysis of the updated sea level data obtained from the main Estonian coastal tide gauges over the period 1842-2009, to assess storm surge risks and to discuss climate change related mitigation and management issues in the coastal zone of Estonia.

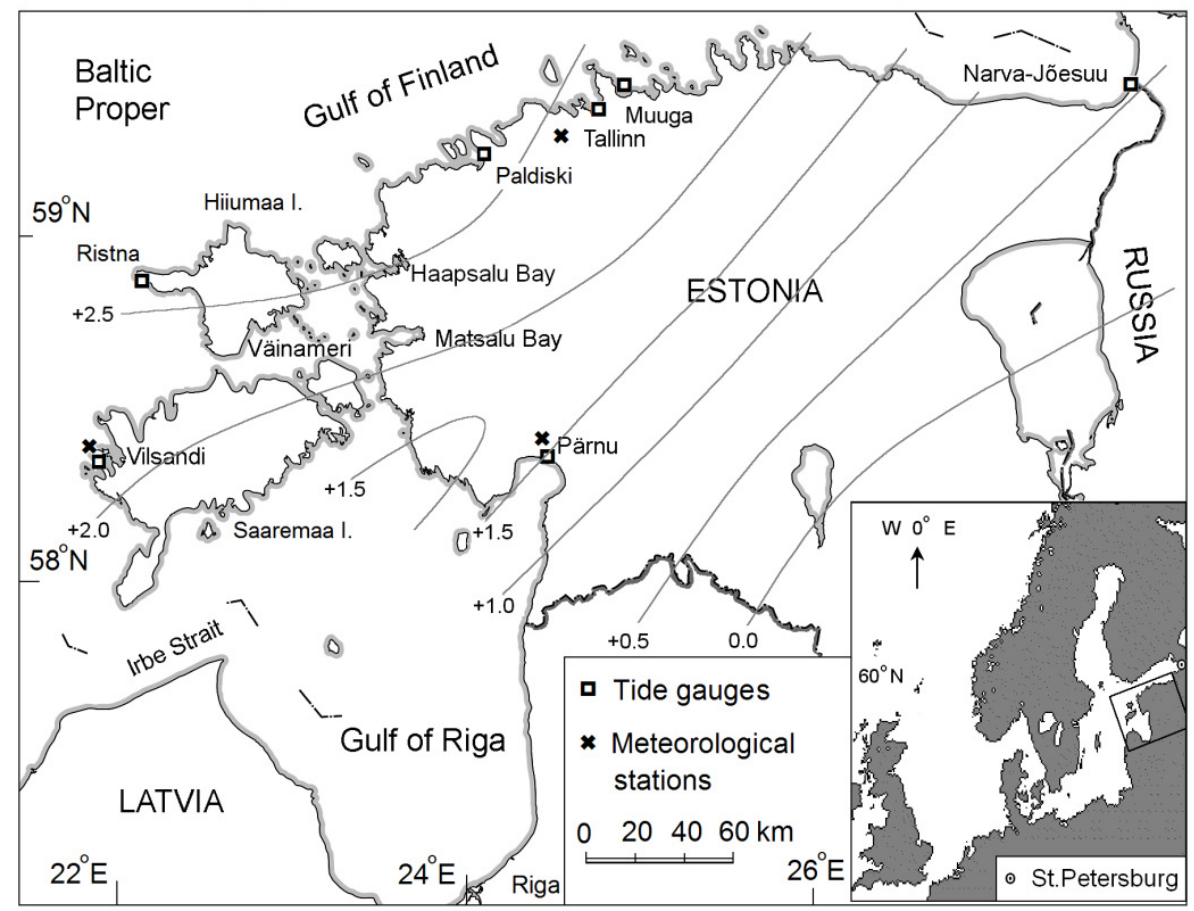

Fig.1. Map of the study area together with the locations of selected meteorological and tide gauge stations and isobases, which express the local land uplift rates (in $\mathrm{mm} / \mathrm{yr}$, according to Vallner et al. [1988]).

\section{The data}

The number of tide gauges currently operated by the Estonian Meteorological and Hydrological Institute (EMHI) is 12. In addition several automatic tide gauges have been recently put into operation at some ports (e.g. Muuga, Tallinn, Sõru, Sillamäe, Paldiski). Most of the tide gauges are equipped with tide poles and have a sampling frequency of 2, 3 or 4 times a day. Automatic tide gauges, currently operated by the EMHI, which provide hourly data, are located only at Pärnu, Narva-Jõesuu and Ristna (Fig. 1). In Tallinn, the capital city of Estonia, sea level measurements started in 1809. The near-continuous data sets are available from 1842 (Fig. 2). Unfortunately, the measurements were discontinued and 
transferred to the Muuga Bay in 1996 due to problems related to local land subsidence and construction work at the port. The merging of the historical EMHI data with the new data collected by the Port of Tallinn has not yet occurred.

\begin{tabular}{ll} 
Time series & Years covered (may include missing months) \\
\hline Tallinn (mean) & $1842-1882,1886-1917,1923-40,1945,1947-96$ \\
Tallinn (extremes) & $1899-1917,1923-40,1945,1947-96$ \\
Narva-Jõesuu & $1899-1915,1923-43,1945-2009$ \\
Pärnu & $1923-2009$ \\
Vilsandi & $1884-1886,1888-1913,1924-44,1949-80$ \\
Ristna & $1950-2009$ \\
Paldiski & $1950-2009$
\end{tabular}

Fig. 2. Time series of mean and extreme sea level available for the investigated tide gauges.

In the present study, data from only those selected tide gauge stations which offer the most extensive and reliable data were considered (Fig. 2). The height system used in Estonia and in other Baltic states of the former Soviet Union is called the Baltic Sea Height System 1977 with its reference zero-benchmark at Kronstadt near St. Petersburg [Lazarenko, 1986]. The Kronstadt zero was defined as the average sea level of that tide gauge in 1825-1840. As a result of global sea level rise, the Kronstadt zero is not the present-time mean sea level of this tide gauge. According to the data published by Bogdanov et al. [2000], the mean was 5.9 $\mathrm{cm}$ in 1971-1993. Instead, the mean sea level of Estonian tide gauges is roughly around the Kronstadt zero now [Suursaar and Sooäär, 2007].

\section{$3 \quad$ Long-term tendencies}

As a result of Fennoscandian postglacial uplift, which can reach up to $8-9 \mathrm{~mm} / \mathrm{yr}$ in some Finnish tide gauges, the sea level records from Finland and Sweden mainly exhibit decreasing trends [e.g. Emery and Aubrey, 1991; Johansson et al., 2001]. The land uplift is considerably smaller in Estonia. According to the repeated levelling surveys, it varies between 0.5 and $2.8 \mathrm{~mm} / \mathrm{yr}$ (Fig. 1) in the coastal areas of Estonia [Vallner et al., 1988]. Thus, in Estonia, the local land rise and global sea level rise (being about 1.5-2 mm/yr during the $20^{\text {th }}$ century [e.g. Church and White, 2006; IPCC, 2007]) roughly balance each other out.

Still, the time series representing annual mean sea levels show increasing tendency at Pärnu (1.2 mm/yr in 1924-2009), Narva-Jõesuu (1.4 mm/yr in 1945-2009), Tallinn and Vilsandi, and yet decreasing trends at Ristna (-1.0 mm/yr in 1950-2009) and Paldiski (Fig. 3). Moving averages of annual mean sea level series show 30-40 year cycles (Fig. 3). Hence, the trend slope estimates somewhat depend on chosen terminal points and lengths of time series. For example, the series of Narva mean sea level for 1899-2009 starts "high" and ends "low" (Fig. 3 ) and the linear trend estimate probably underestimates the real tendency. 


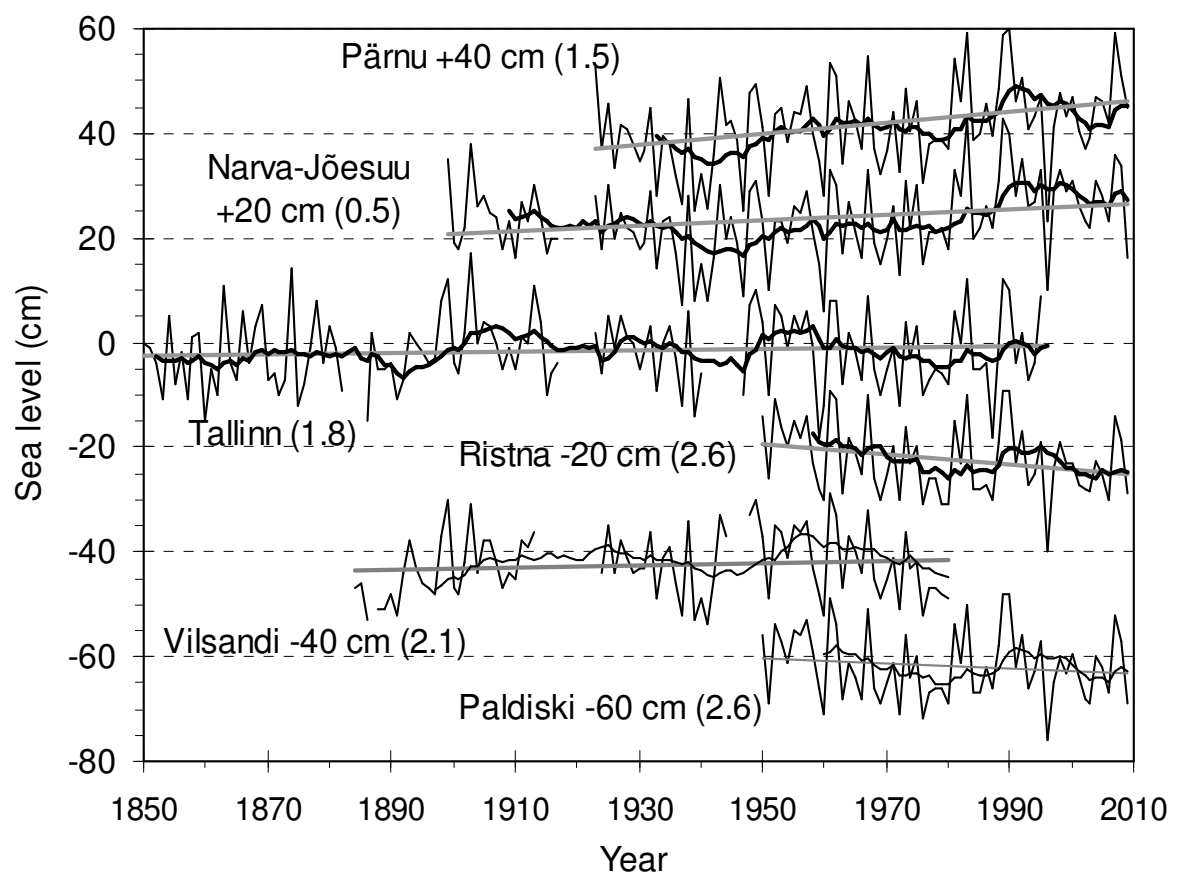

Fig. 3. Decadal variations in annual mean relative sea levels together with 11-year moving averages and linear trendlines (data updated until the end of 2009). The series are not corrected with land uplift rates, and thus exhibit the isostatic land rise together with the climatological sea level rise component. The data of different tide gauges are shifted by 20 $\mathrm{cm}$ regarding each other for clarity.

Corrected with local uplift rates, the mean sea level rise rates for Tallinn, Narva and Ristna are roughly equal to or insignificantly higher than the global estimates [e.g. Church and White, 2006; IPCC, 2007]. However, even considering possible uncertainties in data quality and land uplift rates, the "climatological" sea level trend estimates for Pärnu tide gauge seem to be significantly higher $(2.4-2.7 \mathrm{~mm} / \mathrm{yr})$ than the global one.

The excessive Pärnu sea level rise rate (Fig. 3) over the global estimates can be explained by an anomaly, which was studied in a hydrodynamic modelling experiment [Suursaar and Kullas, 2006]. These results indicate that in case of an obvious decadal trend in wind conditions the sea level change rates of a semi-enclosed basin may deviate from the global estimates. A positive trend in wind speed and storminess should result in a steeper than average sea level trend on the windward side and one that is less steep on the leeward side. Indeed, a clear increase in the westerly wind component occurred between 1950 and 1990 [Alexandersson et al., 1998; Jaagus et al., 2008]. Increase in the western wind component by a magnitude of $2-3 \mathrm{~m} / \mathrm{s}$ reported for the last 50 years may account for up to a $5 \mathrm{~cm}$ locally elevated mean sea level at Pärnu [Suursaar and Kullas, 2006]. The crucial role of changes in wind climate could be confirmed by large change rates in maximum relative sea levels, ranging between 1.9 and $12 \mathrm{~mm} / \mathrm{yr}$ (Fig. 4a), while the rates in minima are between -0.7 and $1.9 \mathrm{~mm} / \mathrm{yr}$. Positive sea level trends both in annual mean (Fig. 4b) and maximums time series mostly appear due to the more steep (positive) trends in winter (December to March) sea level. 

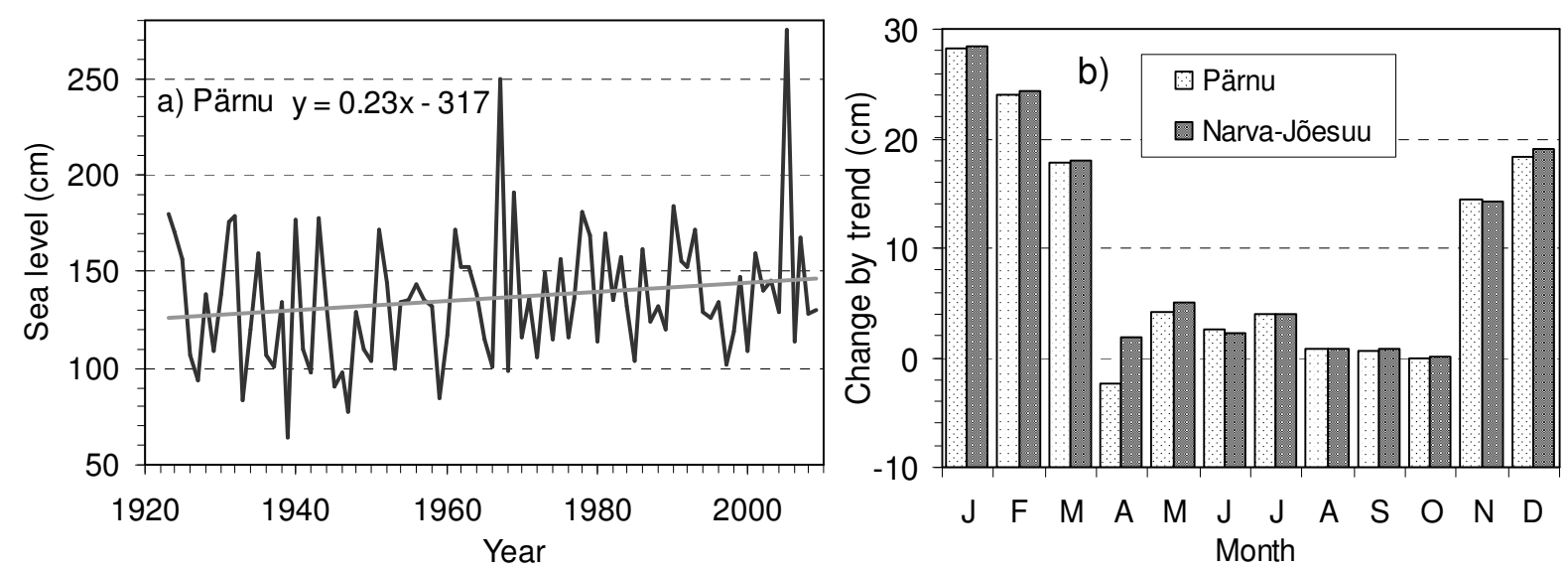

Fig. 4. Decadal variations in annual maximum sea levels at Pärnu (a). Seasonal structure of mean sea level changes by linear trend at Pärnu (1924-2009) and Narva-Jõesuu (18992009). The trend slopes are multiplied with the number of years (86 in Pärnu and 111 in Narva-Jõesuu).

\section{$4 \quad$ Extreme events}

Typically for practically tideless water bodies, sea level tends to fluctuate close to the mean state and even the annually expected maximum sea level is only about $80 \mathrm{~cm}$ (Fig. 5). Still, the historical sea level variability range is rather large (up to $400 \mathrm{~cm}$ at Pärnu) and $150 \mathrm{~cm}$ is expected once in every 3-4 years (Fig. 5a). A sea level rise of $150 \mathrm{~cm}$ is usually critical in the coastal waters of Estonia, and $200 \mathrm{~cm}$ is catastrophic.

Trend analyses have shown that storm surges are becoming higher both in Estonia (Fig. 4a), as well as in Western Europe [e.g. Lowe et al., 2001]. Over the period 1923-2009, the Pärnu sea level record identifies 30 individual events higher than the critical value of $150 \mathrm{~cm}, 24$ of which occurred between the months of October-March and 6 between the months of AprilSeptember. The two highest sea level events off the Estonian coast (since 1923) were both registered at Pärnu: $253 \mathrm{~cm}$ on 19 October 1967 and $275 \mathrm{~cm}$ on 9 January 2005 (Fig. 4a). Strong east winds lower the sea level in the Estonian coastal waters, and west winds raise it [Suursaar et al., 2006]. This applies to both short-time variations (i.e. local surges), as well as for low-frequency variations through corresponding changes in the Baltic seawater volume. The high sea level events are mainly associated with north European cyclonic storms. The centre of a powerful and fast moving cyclone should bypass Estonia to the north over the Scandinavian Peninsula and Bothnian Sea to make the local wind direction turn from SW to NW. Less friction above the sea surface and the elongated shape of the Baltic Sea together with the Pärnu Bay (in case of Pärnu tide gauge) or Gulf of Finland (for Narva-Jõesuu and St. Petersburg) provides a span for surge waves to increase towards the east, as depth also diminishes and the gulf width converges [Suursaar et al., 2006]. The event on 9 January 2005 was produced by the cyclone Gudrun, which achieved hurricane strength winds according to mean wind speed measurements (up to $34 \mathrm{~m} / \mathrm{s}$ ) in Denmark. Another factor contributing to Gudrun's storm surge was the relatively high background sea level in the Baltic $(70 \mathrm{~cm})$ at the time. The higher background sea level was the result of strong cyclonic 
activity during the preceding month, which had the effect of pushing additional water through the Danish Straits into the Baltic Sea.

\section{$5 \quad$ Analysis of extremes - a tool for coastal management}

For coastal zone planning and management purposes it is important to have an idea of the possible extreme sea levels that can ever be expected. The plots of empirical return periods against the corresponding theoretical (e.g. Gumbel) distributions [Suursaar and Sooäär, 2007] showed a more or less a satisfactory fit in all cases except Pärnu maxima. No extreme value distributions could probably describe or predict the two extreme sea level events of 253 $\mathrm{cm}$ or $275 \mathrm{~cm}$ (Fig. 5a). There may exist a mistaken belief that as soon as we discover the "right" theoretical distribution function, we can extrapolate the return period outside the length of the empirical series. Evidently, an estimation of certain extreme events in relation to long return periods can be valid for certain established climatological equilibrium and changes in meteorology will lead to future changes in the return periods of extreme events. However, the changes in empirical response data cannot follow the ongoing climatological changes fast enough, as extreme events are rare anyhow.

Thus, the existing bulk of the data does not carry sufficient statistical information about possible extreme sea level values at Pärnu, as the most extreme values seem to appear "outside" the system. The Pärnu graph is similar to a graph for gust wind speed records that is contaminated by occasional tornados [e.g. Cheng and Yeung, 2002], or sea level data that includes abnormal tsunami events. These two anomalous and outlying values at Pärnu were nevertheless caused by normal storms. Due to the specific configuration of the Gulf of Riga and Pärnu Bay, the sea level is proportional to the wind speed value in the power of 2.4 [Suursaar et al., 2006]. At the upper range of wind speeds, a slight incremental increase in wind speed yields an exponentially higher incremental increase in storm surge level. According to sensitivity runs of the hydrodynamic model [Suursaar et al., 2006; Suursaar and Kullas, 2006] and considering the $30 \mathrm{~m} / \mathrm{s}$ sustained wind speed (which has occurred about 12 times in the last 50 years), the wind direction of SW and the Baltic mean (background) sea level of $60-70 \mathrm{~cm}$, the maximum sea level may reach $310 \mathrm{~cm}$ at Pärnu. At Tallinn, NarvaJõesuu and Ristna, the possible extremes (up to 200-220 cm, Fig. 5) can also be predicted statistically.

Considering the shallow sea, low-lying hypsometric curve, and virtual absence of tides, the local residents are not always sufficiently prepared for such, nevertheless rare, events. The recent catastrophic 2005 surge at Pärnu offered some valuable lessons and initiated profound changes in risk awareness. These lessons, it appears, had been forgotten since the previous surge with nearly comparable height $(253 \mathrm{~cm})$ occurred 38 years earlier. Some previous building standards and legislative acts had been discontinued due to changes in political and economic courses. While centuries old buildings with high basements suffered little at Pärnu, Haapsalu and Kuressaare, numerous new developments were built within reach of even less than $200 \mathrm{~cm}$ sea level rise. Thus, the second crucial aspect of coastal zone management is the dissemination of scientific knowledge among the authorities and residents at storm surge prone areas. In Estonia, EU funded projects, such as ASTRA ("Developing Policies and Adaption Strategies to Climate Change in the Baltic Sea Region" 2005-2008) [Kont and Tõnisson, 2009], as well as ongoing CLIMARISK and BALTSEAPLAN, have played a considerable role in this regard. 

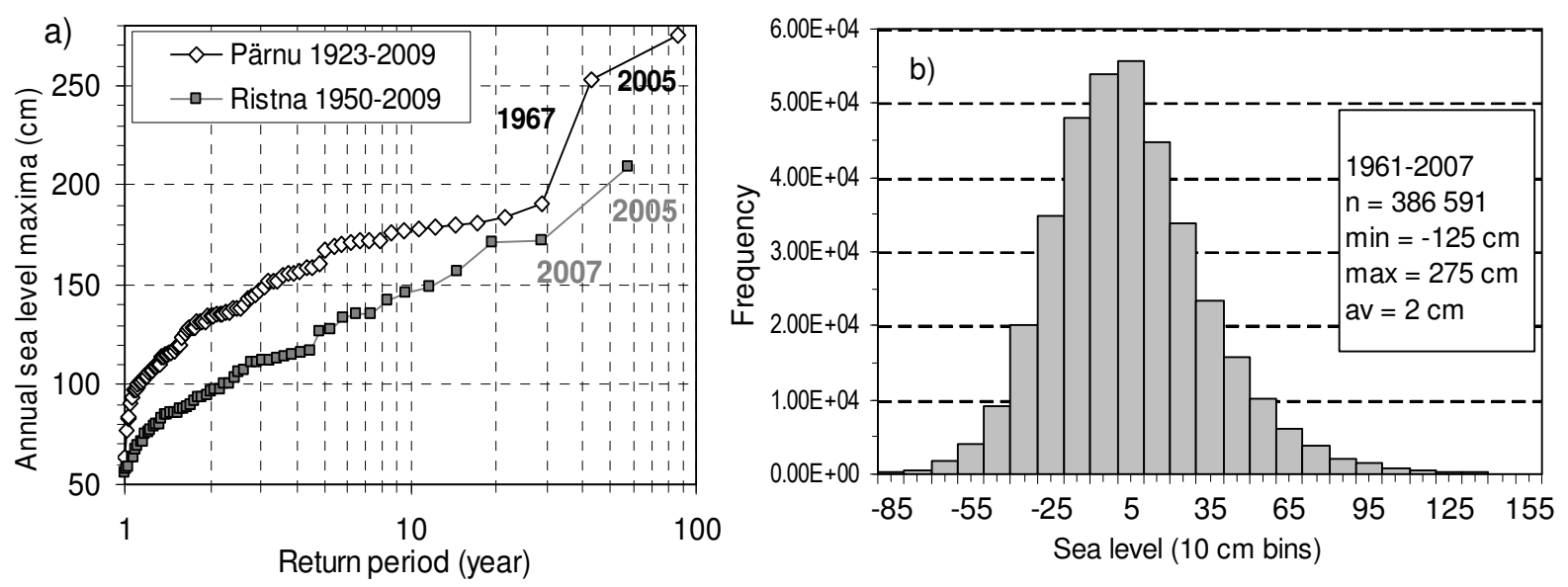

Fig. 5. Empirical return periods based on annual maximum sea level data at Pärnu and Ristna (a), and empirical frequency distribution of Pärnu hourly sea level data (b).

\section{Conclusion}

Sea level variations in the eastern section of the semi-enclosed and practically tideless Baltic Sea are predominantly meteorologically forced, which may include occasional, but very high, sea level events. Trend analysis of the Estonian sea level data from the period 1842-2009 showed that at Tallinn, Ristna and Narva-Jõesuu tide gauges the mean sea level change rates (before adjustment for land uplift) varied between -1 and $+2 \mathrm{~mm} / \mathrm{yr}$. The sea level trend was in all cases positive in winter. The excessive rise in annual maxima (2-12 mm/yr) could be explained by the local sea level response to the changing regional wind climate. In the Pärnu Bay the statistical fit of maximum values distributions for 1923-2009 are inconsistent with the data from the two highest storm surges of $253 \mathrm{~cm}$ (in 1967) and $275 \mathrm{~cm}$ (in 2005). In statistical terms they appear as outliers, or elements of some other population. On the basis of a hydrodynamic modelling study, the height of the maximum expected storm surges could be estimated at $310 \mathrm{~cm}$ during the current climatological epoch, without considering the possible global sea level rise acceleration. Increasing the awareness of climate change related sea level rise issues, and disseminating the relevant scientific knowledge, is of crucial importance.

\section{Acknowledgements}

This work was supported by the ESF grants 7609 and 7564. Special thanks to D.A. Willis.

\section{References}

Alexandersson H., Schmidt T., Iden K. and Tuomenvirta H., 1998. Long-term variations of the storm climate over NW Europe. The Global Atmos. Ocean. Syst., 6, 97-120.

BACC, 2008. Assessment of Climate Change for the Baltic Sea Basin, Springer-Verlag, Berlin, Heidelberg, 473 pp. 
Bogdanov V.I., Medvedev M.Yu., Solodov V.A., Trapeznikov Yu.A., Troshkov G.A. and Trubitsina A.A., 2000. Mean monthly series of sea level observations (1777-1993) at the Kronstadt gauge. Reports of the Finnish Geodetic Institute 2000:1, Kirkkonummi, Finland.

Church J.A. and White N.J., 2006. A 20th century acceleration in global sea-level rise. Geophysical Research Letters, 33, L01602.

Cheng E. and Yeung C., 2002. Generalized extreme gust wind speeds distributions. Journal of Wind Engineering and Industrial Aerodynamics, 90, 1657-1669.

Emery K.O. and Aubrey D.G., 1991. Sea levels, land levels, and tide gauges. SpringerVerlag, New York, Berlin, Heidelberg, 237 pp.

IPCC, 2007. Climate change 2007: The physical science basis, Contribution of Working Group I to the Fourth Assessment report of the Intergovernmentla Panel on Climate Change, S. Solomon, D. Qin, M. Manning, Z. Chen, M. Marquis, K.B. Averyt, M. Tignor, H.L. Miller (eds.), Cambridge Univ. Press, New York, 996 pp.

Jaagus J., Post P. and Tomingas O., 2008. Changes in storminess on the western coast of Estonia in relation to large-scale atmospheric circulation. Climate Research, 36, 29-40.

Johansson M., Boman H., Kahma K.K. and Launiainen J., 2001. Trends in sea level variability in the Baltic Sea. Boreal Env. Res., 6, 159-179.

Kont A., Jaagus J. and Aunap R., 2003. Climate change scenarios and the effect of sea-level rise for Estonia. Global and Planetary Change, 36, 1-15.

Kont A. and Tõnisson H. (eds.), 2009. Climate change impacts on Estonian coasts. The results of the ASTRA Project. Institute of Ecology at Tallinn University. Publication 11/2009, Tallinn, $146 \mathrm{pp}$.

Lazarenko N.N., 1986. Variations of mean level and water volume of the Baltic Sea. In: Water Balance of the Baltic Sea. Baltic Sea Environm. Proc., 16, 64-80.

Lowe J.A., Gregory J.M. and Flather R.A., 2001. Changes in the occurrence of storm surges around the United Kingdom under a future climate scenarion using a dynamic storm surge model driven by the Hadley Centre climate models. Climate Dynamics, 18, 179-188.

Smith D., Raper S.B., Zerbini S. and Sanchez-Arcilla A., 2000. EUR 19337 - Sea level change and coastal processes - implications for Europe. Office for Official Publications of the European Communities: Luxembourg, $247 \mathrm{pp}$.

Suursaar Ü. and Kullas T., 2006. Influence of wind climate changes on the mean sea level and current regime in the coastal waters of west Estonia, Baltic Sea. Oceanologia, 48, 361383.

Suursaar Ü., Kullas T., Otsmann M., Saaremäe I., Kuik J. and Merilain M., 2006. Cyclone Gudrun in January 2005 and modelling its hydrodynamic consequences in the Estonian coastal waters. Boreal Env. Res., 11, 143-159.

Suursaar Ü. and Sooäär J., 2007. Decadal variations in mean and extreme sea level values along the Estonian coast of the Baltic Sea. Tellus A, 59, 249-260.

Vallner L., Sildvee H. and Torim A., 1988. Recent crustal movements in Estonia. Journal of Geodynamics, 9, 215-223. 